\title{
Carboxyamidotriazole Orotate
}

National Cancer Institute

\section{Source}

National Cancer Institute. Carboxyamidotriazole Orotate. NCI Thesaurus. Code C91090.

The orotate salt form of carboxyamidotriazole (CAI), an orally bioavailable small molecule with potential antiangiogenic and antiproliferative activities. Carboxyamidotriazole binds to and inhibits non-voltage-operated calcium channels, blocking both $\mathrm{Ca} 2+$ influx into cells and $\mathrm{Ca} 2+$ release from intracellular stores, resulting in the disruption of calcium channel-mediated signal transduction. CAI inhibits PI3 activity and vascular endothelial growth factor (VEGF) signaling. This may inhibit endothelial proliferation, tumor cell growth, invasion and metastasis. 